\title{
TOWARDS A DEVELOPMENT MODEL OF LOCAL CULTURAL TOURISM THROUGH THE INVOLVEMENT OF LOCAL ACTORS (PROVINCE OF CONSTANTINE, ALGERIA)
}

\author{
Sabrina BOULHILA* \\ Université des Sciences et de la Technologie Houari Boumediene, \\ Department of Geography and Territorial Planning, Algiers, Algeria, e-mail: sabi.boulhi91@gmail.com. \\ Mohamed ALOUAT \\ École Normale Supérieure de Bouzereah, PhD, Geography and Regional Planning, \\ Laboratory of History, Civilization and Applied Geography, Algiers, Algeria, e-mail: alouat777@yahoo.fr
}

Mohamed A. REZZAZ

Université des Sciences et de la Technologie Houari Boumediene, Department of Geography And Territorial Planning, Algiers, Algeria, e-mail: drezmas@yahoo.fr

\section{Serge SCHMITZ}

Université de Liège, Laboratory for the Analysis of Places, Landscapes and European Countryside Laplec Liege, Belgium, e-mail: S.Schmitz@uliege.be

\begin{abstract}
Citation: Boulhila, S., Alouat, M., Rezzaz, M.A., \& Schmitz, S. (2022). TOWARDS A DEVELOPMENT MODEL OF LOCAL CULTURAL TOURISM THROUGH THE INVOLVEMENT OF LOCAL ACTORS (PROVINCE OF CONSTANTINE, ALGERIA). GeoJournal of Tourism and Geosites, 40(1), 9-19. https://doi.org/10.30892/gtg.40101-797
\end{abstract}

\begin{abstract}
Since the nineties, cultural tourism is considered as a form of tourism that is carried out by groups of people or institutions, whose main motive is the fulfillment of an interest and knowledge more on the culture, the history and the heritage of the chosen destination. The city of Constantine, located in northeastern Algeria, is one of the oldest cities in the Mediterranean basin. It was elected "Capital of Arab Culture 2015" due to its history, cultural and architectural heritage. The aim of this study is to examine the influences of cultural tourism on local development, to highlight the perception of local actors' roles in the development of tourism and to determine their involvement in the preservation of Constantine's cultural heritage to achieve a development model of cultural tourism in Constantine. This study is based on a literature review and field surveys, the type of questionnaire includes different types of questions: open questions, Likert scale questions and multiple choice qualitative questions. A manual processing of the data was performed using the mean and standard deviation calculation. The results of this study reveal a misunderstanding of cultural tourism among local residents hence the need to develop a model of categorization of the objectives of the study (SPIP) which proposes four key principles for the development of local cultural tourism in the city of Constantine. However, unless the proposed model elements are incorporated, cultural tourism in this city would never emerge.
\end{abstract}

Key words: Cultural tourism, city of Constantine, influence, local development, heritage, local actors, tourism development model

$* * * * * *$

\section{INTRODUCTION}

Tourism is a vital source of foreign exchange income for many countries and contributes significantly to the economy by creating jobs and providing opportunities for development. According to the UNWTO report entitled "UNWTO Tourism Highlights, 2014 Edition", international tourist arrivals in Europe showed a solid growth rate of 5\% in 2013, up by 29 million compared to 2012, giving a total of 563 million. The World Tourism Organization report in 2014 ranks Algeria 4th tourist destination in Africa and was 111th on the international tourism scene (Belkhiri, 2018) with its 2.7 million foreign tourists in 2013 which despite its clear progression compared to 2012, remains in decline in comparison to the numbers recorded in Morocco (10.2 million tourists) and Tunisia (6.3 million tourists) World Economic Forum (FEM, 2013). The black decade and maybe the influence of oil in the Algerian economy have contributed to this decrease. The absence of an intersectoral synergy has made Algeria incapable of meeting the national demand and attracting international tourists (Baouali et al., 2019). Cultural tourism is a type of tourism activity in which the visitor's essential motivation is to learn, discover, experience and consume the tangible and intangible cultural attractions/products in a tourism destination (Richard, 2013). Since the ancient Romans visited Greece and Egypt, people have traveled for what we now call cultural reasons (Perrottet, 2002). On tour operators' consumer websites, the term "cultural tourism" refers to a niche market where cultural tourism would be a clean, elegant form of tourism that is respectful of the host destinations and communities (Lekane and Schmitz, 2012). The archaeological sites and heritage assets of a territory are key elements that attract tourists who wish to discover monuments and sites outside their usual places of residence, all of which are part of the components of "cultural tourism" (Kherrour et al., 2020). People move to cities outside their usual places of residence to gather new

\footnotetext{
* Corresponding author
} 
information and experiences, as they seek out all the major features of culture in the place they visit, including monuments, heritage sites, museums and gastronomy (Du Cros and McKercher, 2014). In many regions and cities, we observe a growing interest in the potential of tourism and culture as a major attraction and strategic force for economic growth. (Girard and Nijkamp, 2009) In the context of the cultural tourism market, an analysis of the role of the different groups involved and affected by tourism development reveals the main target actors involved in the development of the tourism industry, with tasks, objectives and activities that determine the development of the industry (Figure 1).

In addition, the non-profit organizations that are mainly civil organizations including local and regional non-profit cultural associations and non-governmental organizations (NGOs), arts institutions and cultural heritage entertainment, action groups, volunteer groups and cultural activists should not be overlooked, not to mention the academic body represented by universities, educational institutes and schools, including their teachers, scientific researchers and doctoral students with a vision of shaping the tourism industry's future development, targeting various tourism market actors planners, auditing and policy advice (Šćitaroci et al., 2019). Destination management should synergistically support local stakeholders to improve the diversity and quality of the tourism offer (Corak and Borani'c, 2017). This study highlights important aspects of the cultural tourism development in Constantine, a city located in the east of Algeria that has a unique architectural and urban heritage still largely unknown. Constantine is a city of creativity in every nook and cranny of the sites goes back in time to offer both man and the land traditions and customs that constitute a unique heritage which distinguishes it from other cities in the world that surround it. Although tourism does not occupy an important place in the political priorities of the Algerian state and cultural tourism never emerged in this thousand year old city despite all its cultural and heritage wealth. It should be known that cultural tourism is a positive image carrier for the city and for the country in general and contributes to its local development. Therefore, this work focuses mainly on the idea of establishing a local cultural tourism development model in Constantine in order to attract public interest in Constantine and make its cultural heritage and territory a tourist destination. The positive effects of tourism is the main motivation for the development of tourism in any region, affirmed by many studies already conducted on the impact of tourism on the attitude of the inhabitants. It also determines the perception of the citizens in relation to the development of cultural tourism in their city and the importance of all parties' involvement in order to preserve the city's heritage assets. The inhabitant can become the main actor in the development of cultural tourism because he plays a decisive role in the preservation of cultural heritage and can be the key element for the promotion of this type of tourism (Waridin and Astawa, 2021). Far from the inspirations and expectations of this strategic sector, the development of tourism cannot be achieved without the development of a model that combines all development objectives and involves all stakeholders. In this regard, the following four, questions will guide our study:

Does cultural tourism have an influence on the local development of a territory?

How do the local inhabitants perceive the development of cultural tourism in their city?

What is the role played by local actors in the preservation of the cultural heritage of the city of Constantine?

What is the adequate model to make the territory of Constantine and its cultural offer a tourist destination?

\section{LITERATURE REVIEW}

\section{Cultural heritage as a new economic resource:}

Before addressing this topic, it is important to define cultural heritage, various researchers defined cultural heritage among the most common definitions, "UNESCO" defines cultural heritage as "the heritage of tangible or intangible property of humanity or society inherited from previous generations, preserved in the present and left to future generations." Tangible heritage includes heritage worthy of preservation, such as

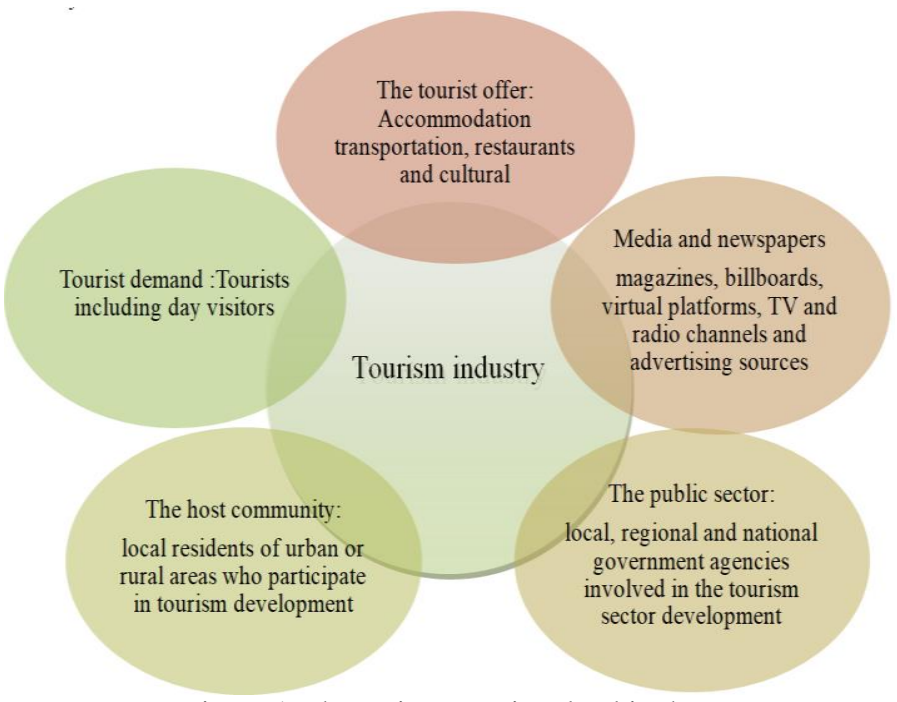

Figure 1. The main actors involved in the development of the tourism sector (by the authors)

buildings, monuments and works of art. Intangible heritage refers to oral traditions, customs, performing arts, life experience and knowledge used to produce traditional crafts. Existing research on the exploitation of cultural heritage as a new economic resource has provided information of an exploratory nature that is mainly descriptive, and the review of the research presents various positive results on this topic. The work of (Janssen et al., 2017; Morar et al., 2020; Zuo et al., 2017) focused on the idea of using heritage assets as a service that is economically viable, increase employment, generate income for local communities and attract new investment opportunities so that local communities can appreciate their values through the improvement of quality of life as well as fostering a sense of local belonging. According to the study of (Timothy, 2014) "an associate professor at the school of community resources and development, editor of the journal of heritage tourism" in his article titled "contemporary cultural heritage and tourism" stated in turn that the trend to expand heritage products to include other features that were not previously considered as attractive product by visitors. Archaeological sites are now the biggest challenge to the local economy, bringing in foreign currency and a real source of national income (Rahal et al., 2020). Pecqueur, 2001, "a professor in urban planning and development at the University of Grenoble Alpes in his research work 
"quality and territorial development" has considered each good or specific offer of the territory as a quality product, by the effect of the "basket of goods" this model is based on all the goods of a territory that become subsequently "leading products" that attract and reinforces the overall quality of the territory and attract tourists. The city of Constantine is facing development challenges like all cities, although it does not lack capacities (cultural and natural) that can be used as a new economic source through the creation of projects in the tourism sector and contribution to the local economy by focusing on factors worthy of advancing and mobilizing the development cycle of this city and its territories (Naidja and Benidir, 2017).

\section{The role of local actors in promoting tourism and preserving heritage}

Territorial actors are those who build the image of a tourist destination to strengthen the attractiveness of the region with the aim of attracting the highest number of tourists. The actors' role is to integrate the territory into a tourism policy (Violier, 2008), and previous research indicates that tourism and heritage are linked and often inseparable from each other. Nevertheless, the outcome of this correlation depends on the degree of participation of the general public and the involvement of different actors in the tourism sector in promoting tourism (Lak et al., 2019). Also, tourism helps involve native peoples in exploring development options, and is considered a strategic asset to encourage development in some areas with potential for tourism attraction (Cappuci, 2016; Cárdenas-García et al., 2015; Kodir, 2018). Several authors in this topic, encourage the involvement of communities and locals in tourism development policies. Add to this literature that political decentralization of tourism development from central to local governments is important to ensure effective tourism development and to create a cohesive tourism network in developing countries. The diversity of stakeholders is a crucial factor in the tourism development process, as each stakeholder's position, knowledge and privileges will stimulate the mobilization and performance of the process (Kimbu et al., 2013). Citizen participation in heritage protection is generally achieved through associations that bring together groups to preserve cultural heritage (Drouin, 2004), the awareness of civil society on the importance of heritage in all its dimensions led to increased public involvement in the heritage conservation and positively impacted the quality of some products in historic districts and heritage sites. The current debate on the citizen's contribution to cultural heritage protection focuses on the local environment, so it is important to emphasize that heritage involves the living environment, i.e. citizens, and that the survival of heritage is not limited to preserving it, but to using it so that it can remain dynamic and alive, hence the need for public involvement in the preservation of tangible and intangible cultural heritage (Krim, 2010).

One of the approaches that can be used in the development and planning of tourism studies is the community approach model known as the participatory approach (Prabhakaran et al., 2014). This approach is based on the local community alignments to maintain the local culture and improving its well-being (Ernawati et al., 2014). The community also plays an important role in tourism development (Marlina et al., 2020). However, the community will be encouraged to participate in tourism activities if they know the positive benefits of tourism (Suwantoro, 1997; Thomas, 2007). There are several models of community empowerment development. One is to increase marketing and accessibility, improve quality and service through human resource development (Goodwin, 2002; Astina et al., 2021). The community can actively participate in land use planning (Yankholmes, 2018). Overall the local decision-making involvement is done through the determination of the objectives and resolutions of the latter. This involves the government parties to give voice to the residents and discuss with them to determine their concerns and expectations in tourism, and take into consideration the views of other stakeholders in decision-making, this will even help to raise the standard of living of its inhabitants and even the level of education improves, increasing their income, thus creating job positions, and contributes to the decrease in the unemployment rate (Brohman, 1996).

\section{Cultural tourism impacts on the territory}

Development is too often defined in terms of planning and market efficiency, at the expense of the more generalized improvement or development community residents, is considered a transformation process or change from one state to another more advanced, the term local: often refers to the notion of territory, i. e. the word local development: refers to the stage of territorial transformation (which is carried out at the level of the territory), in its multiple dimensions: political, administrative, cultural, taken in charge by the local actors (Rees and Fasenfest, 1997). Cultural tourism is probably the oldest of the "new" tourism phenomena. People have been traveling for what we now call cultural tourism reasons since Roman times, although this was not previously recognized as a distinct group of travelers. Visiting historical sites, cultural landmarks, attending special events and festivals, or visiting museums have always been part of the overall tourism experience. Indeed, there is a cultural element to all travel (Du Cros and McKercher, 2014). In the classical approach, the territory is called "space" and it is considered as a support that offers resources that can be transformed into attractive territorial products (Alloui-Ami Moussa, 2021). Cultural tourism development provides potential short-and long-term economic tools benefiting communities (MacDonald and Jolliffe, 2003). According to (Cousin, 2008), cultural tourism is "beneficial" for the territories they cover and they condemn the harmful effects of large-scale tourism in local cultural institutions national or international, because is a harmless process, honorable and respectful for the place and fit of the population. Today, the importance attached to culture and towards cultural tourist attractions is increasing, and the recognition of the originality of the cultural property can only bring value for the territory it hosts declared (Grelet and Vivant, 2014). Constantine, during the event "Capital of Arab Culture 2015", benefited from a series of renovation operations carried out on cultural and tourist infrastructures and a rehabilitation and restoration of heritage, as well as a significant number of cultural facilities and tourist infrastructures on its territory. The event policy has proved that Constantine can welcome thousands of tourists every year on its territory, and develop a 
model of local cultural tourism, which could positively influence the development of its territory, while respecting the criteria of sustainable tourism development and respect for heritage (Soualah and Benabbas-Kaghouche, 2017).

\section{STUDY AREA}

The city of Constantine is located in the east of Algeria at a latitude of $36.23^{\circ} \mathrm{N}$ and a longitude of $7.35{ }^{\circ} \mathrm{E}$, thus occupying a distinct region with suitable topography, within the hill atlas between the coastline and the northern border of the desert, as it is $245 \mathrm{~km}$ far from the Algerian- Tunisian eastern borders, $431 \mathrm{~km}$ from Algiers in the west, $235 \mathrm{~km}$ from the town of Biskra in the south, and $89 \mathrm{~km}$ from the town of Skikda in the north. as shown on the map above (Figure 2). The strategic location allowed it to play an important role in the Algerian East, which it mediates geographically through historical functional relations, which increased the importance of the city on the economic, social, cultural and political levels as the meeting point of all land and air transport, and an industrial economic center at the national level, especially in the rank in the ranking of Algerian cities after Algiers and Oran (ONS, 2011). During the reign of Emperor Augustus, the region of Mauritania was ceded to Juba II and Cirta became part of Numidia, itself attached to the province of Africa Nova. The south of Cirta is meanwhile a strictly military sector where luxurious buildings were erected. At the beginning of the third century AD, under the emperor Septimius Severus, Numidia became a separate province. In the 4th century AD, it was the center of Donatism, a heretical Christian movement. Later, the emperor Maxentius succeeded in seizing Cirta and destroyed it completely in the year 311. The reconstruction of Cirta is the work of the emperor Constantine I the Great to which he gives his name. The Numidian city of Cirta thus became Constantine in 313. This new name remained until today with a few changes due to the local dialect based on the Arabic language to produce the present and official name of Constantine. Only a few rare vestiges of Roman Cirta remain, the main ones being the capitol (the current Kasbah) which represented the rampart of the old city, as well as the Triumphal Arch which was the entrance of the capitol (Thomas, 1955).

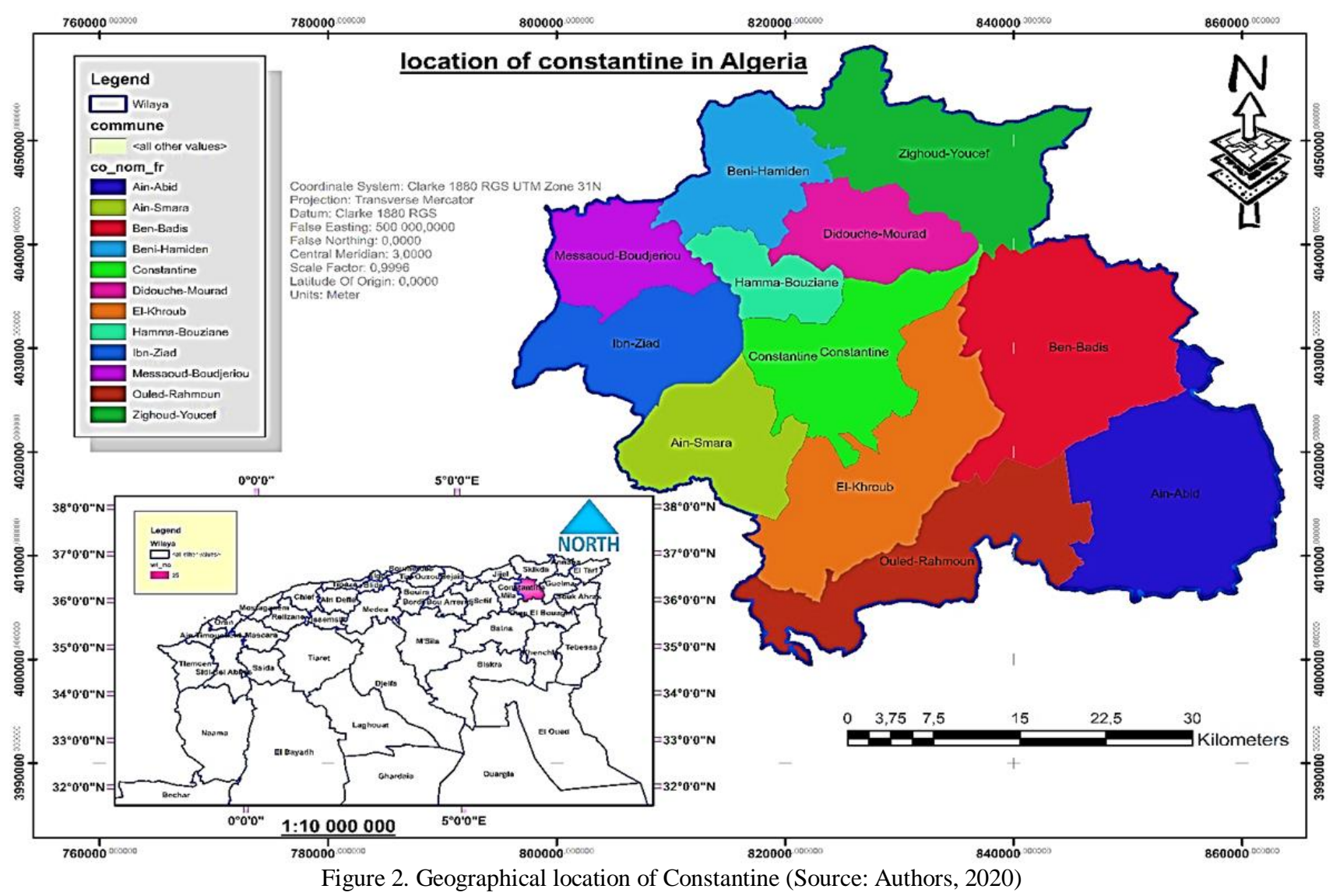

Every square meter of the city is an open-air museum, the different civilizations that have succeeded each other on the territory of Constantine have left their mark through vestiges, some of which have resisted the effects of time, such as: « TIDDIS » Figure 3(a): One of the most important archaeological and tourist sites, is located about thirty kilometers northwest of Constantine «The monument of the dead» Figure 3(b). This funerary monument was built in 1934 to celebrate the memory of the French soldiers who died in the First World War. The medina Figure 3(c): The medina of Constantine is called the "Rock" because it is built on a limestone block. It is built in layers from the Kasbah to the lower districts of the Souika. The religious heritage: Constantine has about a hundred mosques: «The Emir Abdelkader mosque» Figure 3(d), dates back to the 1980s and is part of the Islamic University of Sciences. «The city of suspended bridges»: Among the oldest bridges of Constantine, there is that of «Bab el Kantara » Figure 3(e), built in the second century by the Roman emperor Antonin the Pious, and the bridge of « Sidi Rached » Figure 3(f), is considered the longest stone bridge in the world. «Gardens and orchards»: For a long time Constantine was known for its gardens and orchards, scattered around the 
city. This reputation is still relevant today, Constantine has many public gardens that soften the air of the city and give it a touch of green restful and soothing. Among these green spaces, the Ben Nacer garden, also called garden of the rich, located in the heart of the boulevard of Bab el oued. Without forgetting the forest of « Djebale el ouahch » Figure 3(g), with a total area of $3522 \mathrm{Ha}$, natural space of relaxation implanted in full heart of a dance forest cover .
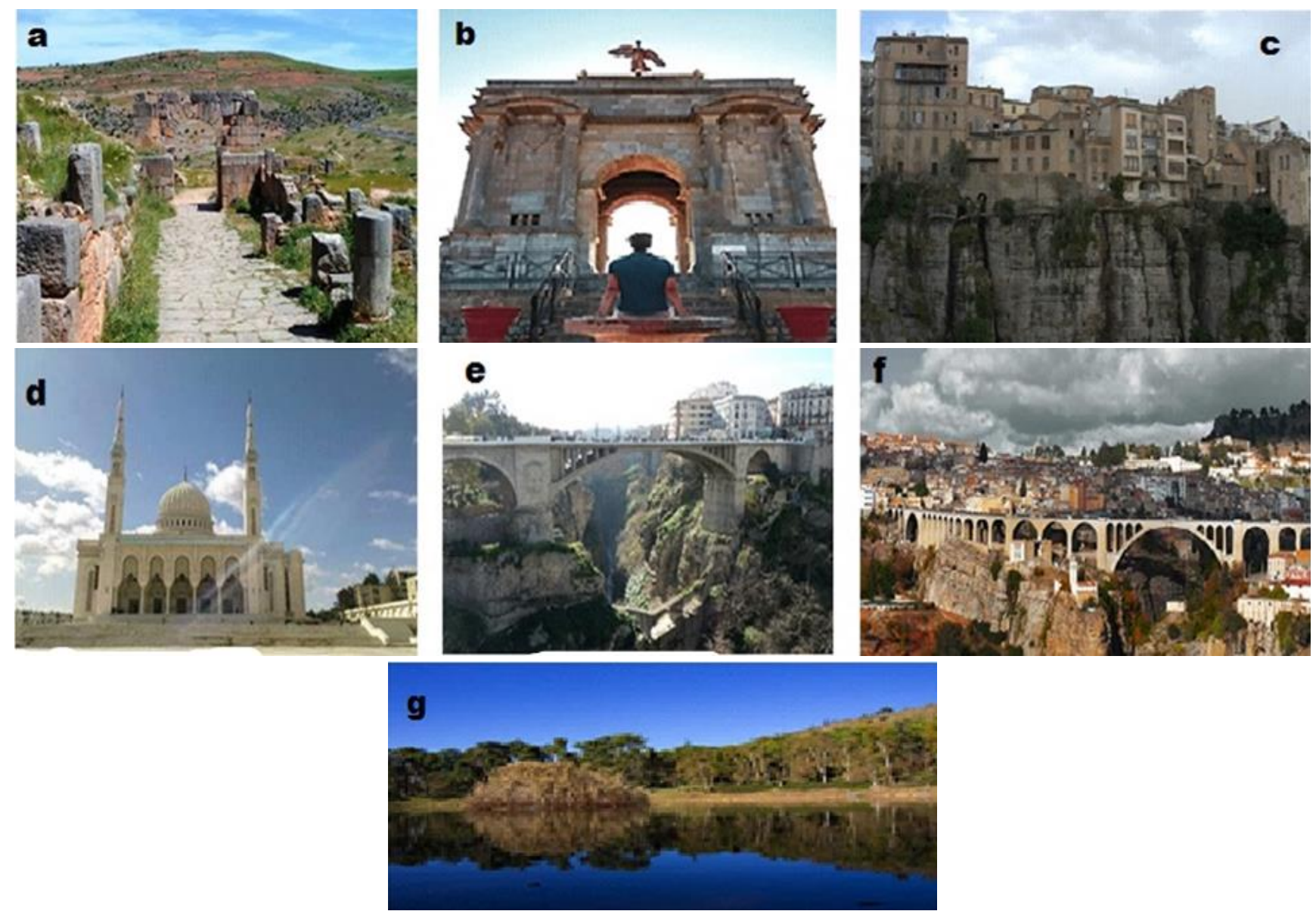

Figure 3.The most well-known cultural and natural heritage assets in Constantine: (a) Tiddis, (b) The monument of dead,

(c)The medina, (d) The Emir Abdelkader, (e) Bab el Kantra, (f) Sidi Rached, (g) Djbal El Ouahch (Source: Taken by the authors 2020)

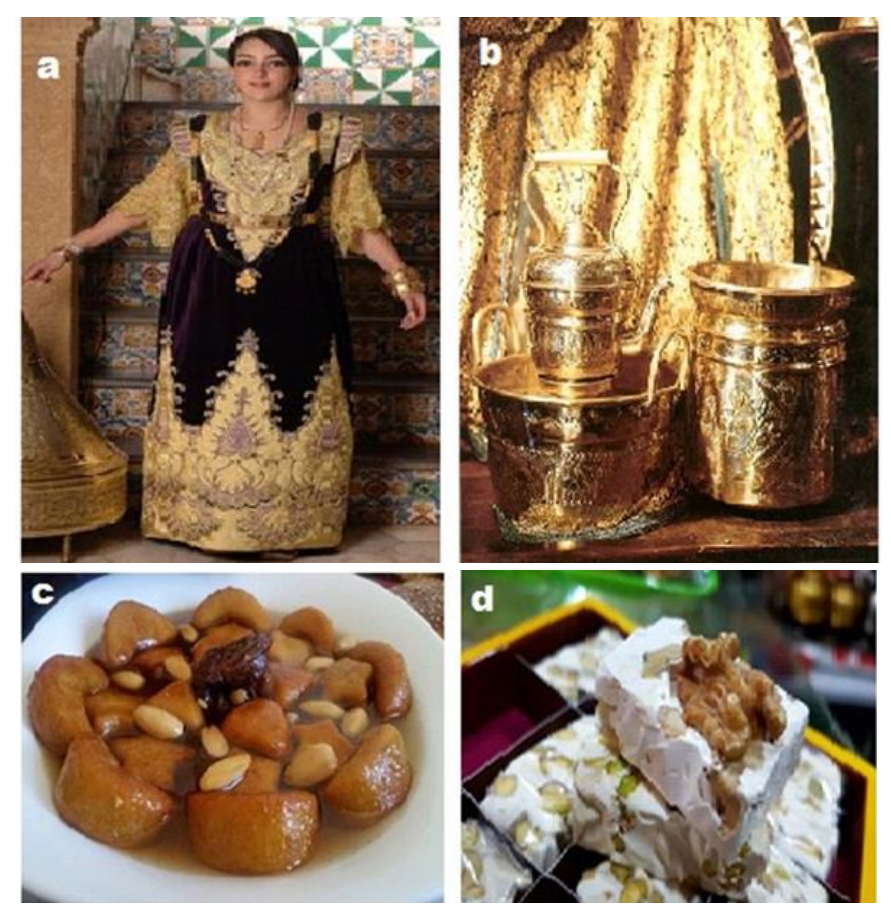

Figure 4.Traditionnal industries: (a)Traditional local dress, (b) Brassware, (c) Chebah Essafra,

(d) Jawzia (Source: Taken by the authors 2020)

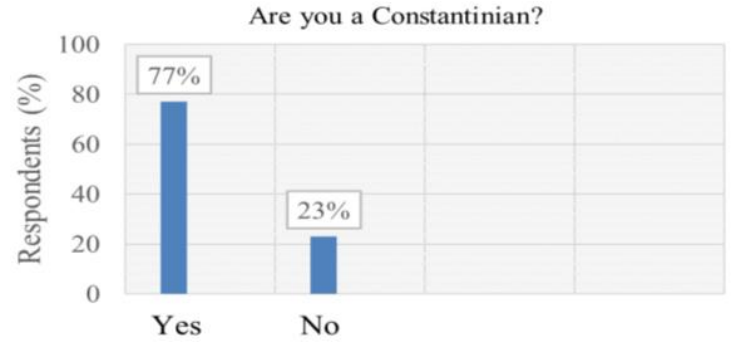

Figure 5. Origins of respondents

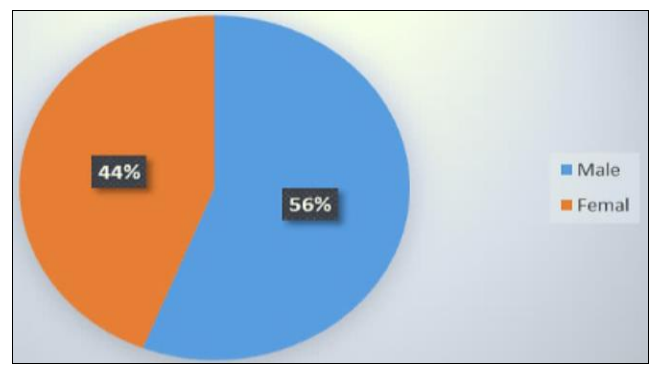

Figure 6. Repartition Male /Femal

Table 1. Cronbach's Alpha Reliability

\begin{tabular}{|c|c|c|c|}
\cline { 3 - 4 } \multicolumn{2}{c|}{} & Number & Percentage \% \\
\hline \multirow{3}{*}{ Observation } & Valid & 305 & 99,7 \\
\cline { 2 - 4 } & excluded & 1 & 0,3 \\
\cline { 2 - 4 } & Total & 306 & 100,0 \\
\hline
\end{tabular}


The city is known for its traditional Constantinian dress Figure 4(a), often associated with traditional jewelry considered to be one of the oldest crafts. Several events and local festivals contribute to the cultural animation of the city: the spring distillation of flowers and roses each year the teqtare the production of essences and aromas is amongst the traditions that have been preserved and passed on from one generation to another. Handicraft activity remains important, including brassware Figure 4(b) and copper trays with Ottoman-inspired motifs. The city also features a rich culinary heritage, both Muslim and Jewish. Among the culinary specialties that are eaten during the month of Ramadan, "Tadjine el Ain", made of prunes with almonds and meat sprinkled with fine sugar, El djari, Chorba made of dried, roasted and crushed wheat, "Chbah essafra" Figure 4(c) There are also many pasta-based dishes from Constantine, such as Chakhchoukha. The local pastry is also varied, such as "jawzia" Figure 4(d) (SDATW, 2013 ).

\section{RESEARCH METHODOLOGY}

In order to understand the close relationship between local actors and cultural heritage towards a development of local cultural tourism, a survey of 20 questions was conducted online from April 15 to May 30, 2020 involving more than 300 people through social networks and groups dedicated to $\mathrm{Ph} . \mathrm{D}$. students and university researchers and several associations active in the promotion of tourism and preservation of cultural heritage in Constantine. $77 \%$ of respondents are inhabitants of Constantine city, the remaining $23 \%$ are from different regions of the country (Figure 5). 56\% of respondents are male (Figure 6). The questionnaire includes different types of questions according to the desired information. Open questions allow the respondents to answer freely and express their opinion on the subject in order to collect clear and precise information. The second category includes Likert scale questions which are often used to judge the degree of satisfaction and agreement. The third category consists of multiple-choice questions that provide the respondent with a list of answers. These qualitative questions are the most common, and their success is due to their ease of processing, which is a reliable and well-structured means of data collection. Indeed, closed questions are suitable for data analysis, whereas answers to open questions require data entry and manual processing. Other issues have disrupted the survey mainly due to COVID-19 crisis that affected people's daily life. The respondent usually does not take the survey immediately when it is sent, or must be reminded to do so at a later date. the questionnaire distributed online does not work properly sometimes because of the strong disruption of the Internet connection in Algeria, for this a telephone survey was used and it remains an effective method but also more expensive. The analysis was carried out to approximate the current situation of tourism development in Constantine and to assess the sample's awareness of cultural tourism development in the city. Cronbach's alpha (Table1) is a practical test often used when a survey/questionnaire includes multiple Likert questions to determine the scale's reliability. In general, if Cronbach's alpha is greater than 0.7 , the scale is considered to be highly correlated. In our case, the results of the survey indicate a $99.7 \%$ alpha coefficient for a list of 20 questions. This suggests that the items have a relatively high internal consistency, which ensures the validity and reliability of the survey.

\section{CHARACTERISTICS SAMPLE}

The survey was distributed to 306 people and collected opinions of local population of Constantine regarding cultural tourism development in their city. The majority of respondents $(77.2 \%)$ were inhabitants of the city, while residents from different Algerian provinces accounted for $22.8 \%$ of the sample indicating that the study was based mainly on the native population. $55.8 \%$ of the sample were men and $44.2 \%$ were women. The age range that dominated was 21 years to 41 years, the majority of them were in higher education (55.2\% have a Bac+5 and 30.1\% have Bac+2). The individuals included in our sample have a relatively high level of education as shown in (Table 2). Finally, students were the most common socioprofessional category (39.2\%), followed by employees (35\%). These results brought us closer to the target category (Table3).

Table 2. Sample profile

\begin{tabular}{|l|c|c|}
\hline \multicolumn{1}{|c|}{ Origin } & Frequency & Percentage (\%) \\
\hline Constantinian & 236 & 77.2 \\
\hline Non Constantinian & 70 & 22.8 \\
\hline Gender : & Frequency & Percentage \% \\
\hline Female & 135 & 44.2 \\
\hline Male & 171 & 55.8 \\
\hline Level of education : & Frequency & Percentage \% \\
\hline Bac+2 & 92 & 30.1 \\
\hline Bac +5 & 169 & 55.2 \\
\hline Primary & 45 & 14.7 \\
\hline Age & Frequency & Percentage \% \\
\hline Less than 20 years old & 44 & 14.3 \\
\hline From 21 to 41 years old & 170 & 55.5 \\
\hline From 42 to 62 years old & 60 & 19.6 \\
\hline 63 years old and more & 32 & 10.4 \\
\hline Total & 306 & $100 \%$ \\
\hline
\end{tabular}

To compute the mean of a series of values presented by intervals, the following formula is used: $\bar{X}=$ Sum of (centers of intervals $X$ their coefficients) / total number.
Table 3. Socio-professional profile of respondents

\begin{tabular}{|l|l|l|}
\hline Socio-professional categ ry: & Frequency: & Percentage \%) \\
\hline Retailer & 18 & 06 \\
\hline Employee & 106 & 35 \\
\hline Worker & 13 & 4.2 \\
\hline Retired & 32 & 10.4 \\
\hline Student & 120 & 39.2 \\
\hline Housewife & 10 & 3.2 \\
\hline Unemployed & 07 & 02 \\
\hline Total & 306 & $100 \%$ \\
\hline
\end{tabular}

Table 4. The local population perception of a cultural tourism development in the city of Constantine (Completed by authors)

\begin{tabular}{|l|c|c|c|}
\hline \multicolumn{1}{|c|}{ The perception of the local population } & Number: & Mean: & Standard deviation: \\
\hline What is tourism cultural according to you & 306 & 1.81 & 0.961 \\
\hline $\begin{array}{l}\text { Constantine has all the assets to make it } \\
\text { an international tourist product }\end{array}$ & 306 & 4.30 & 0.563 \\
\hline $\begin{array}{l}\text { what are the obstacles to the } \\
\text { development of cultural tourism }\end{array}$ & 306 & 3.89 & 0.315 \\
\hline $\begin{array}{l}\text { What do you think of the development } \\
\text { of this type of tourism in Constantine }\end{array}$ & 306 & 3.73 & 0.445 \\
\hline$\sum$ Axe 01 & 306 & 3.43 & 0.57 \\
\hline
\end{tabular}


The standard deviation formula by (Grenier and Modulad, 2007) is :

$$
\mathbf{\sigma}=\sqrt{\sum_{i=0}^{n} \frac{\left.\llbracket x_{i}-\mu\right] z}{n}}
$$

Where " $\sum$ " is the sum, " $x_{i}$ "is the value of the statistical series, " $\mu$ " is its arithmetic mean, and " $\mathrm{n}$ " is its number of respondents.
Table 5. The role of local actors in the preservation of the cultural heritage of their city (Completed by authors)

\begin{tabular}{|l|c|c|c|}
\hline \multicolumn{1}{|c|}{ The role of local actors } & Number & Mean & Standard deviation \\
\hline $\begin{array}{l}\text { In your opinion, how could we raise } \\
\text { awareness of local cultural heritage }\end{array}$ & 306 & 4.24 & 0.544 \\
\hline $\begin{array}{l}\text { Are you willing to invest to increase } \\
\text { awareness of heritage protection }\end{array}$ & 306 & 3.86 & 0.351 \\
\hline $\begin{array}{l}\text { Tourism actors have an active role in the } \\
\text { protection of cultural heritage in your region }\end{array}$ & 306 & 3.96 & 0.253 \\
\hline$\sum$ Axis 2 & 306 & 4.02 & 0.38 \\
\hline Total of the axes & 306 & 3.94 & 0.47 \\
\hline
\end{tabular}

The inhabitants of Constantine are willing to commit their time (and/or) skills to raise awareness about the cultural heritage: the mean for this variable is equal to $\bar{X}=4.24$ and it is higher than the theoretical mean which is equal to (3), with a standard deviation of $\sigma=0.544$. The mean of this variable is the highest in this axis and even exceeded the total mean so the significance is totally positive, this means that the inhabitants of Constantine are convinced by the idea of participating in raising awareness about the cultural heritage of their city. The means of raising awareness of the cultural heritage (tangible and intangible) of the city: the arithmetic mean of this variable is equal to $\overline{\mathrm{X}}=3.86$ it is higher than the theoretical mean (2.5) with a standard deviation $\sigma=0.351$, so the inhabitants of the city know the means of raising awareness of the heritage, and even propose to organize days of awareness on the heritage of the city and involve local associations to take care of it. Evaluation of the level of professionalism of the actors in charge of heritage protection: the average is equal to $\bar{X}=3.96$ and it is higher than the theoretical average (3), with standard deviation $\sigma=0.253$, this indicates that the tourism actors have an active role in the protection of the local heritage of the city of Constantine.

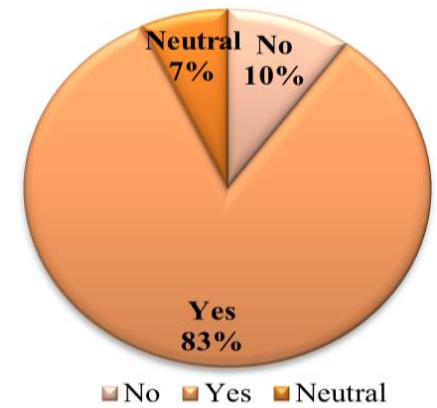

Figure 7. Economic performance of tourism (Own results, 2020)

\section{RESULTS AND DISCUSSION}

According to the results of the survey (Figure7), 83\% of the participants answered yes and believe that cultural tourism development positively contributes to the city's economy and creates viable and profitable economic activities for the local population of Constantine. 10\% from total respondents answered no, justifying their opinions by the lack of professionals and experts in this sector and the need for proper planning and a lot of resources and experience to ensure a return. $7 \%$ from total respondents preferred not to answer this question. The interest of Constantine's inhabitants for their heritage assets is reflected in their answers as shown in Figure 10. Indeed, over half $(55 \%)$ of the respondents totally agree that the city of Constantine has all the assets to become an international tourist destination. $55 \%$ of respondents believe that the cultural heritage of Constantine can be a main element to promote cultural tourism, knowing that $(77 \%)$ of the answers were from the inhabitants of Constantine (Table 2). $42 \%$ of the respondents are willing to invest their time (and/or) skills (and/or) money) to raise awareness about the cultural heritage of Constantine, considering that $70 \%$ of the sample were employees and students, indicating that the majority do not have the means to cover these expenses (Table 3). The people of Constantine are proud of their heritage and are attached to their identity and traditions, so it is necessary to involve them in the upcoming enhancement and preservation projects of the local cultural heritage. When local citizens participate in these projects, they develop a sense of respect for their city that positively reflects on all members of the community.

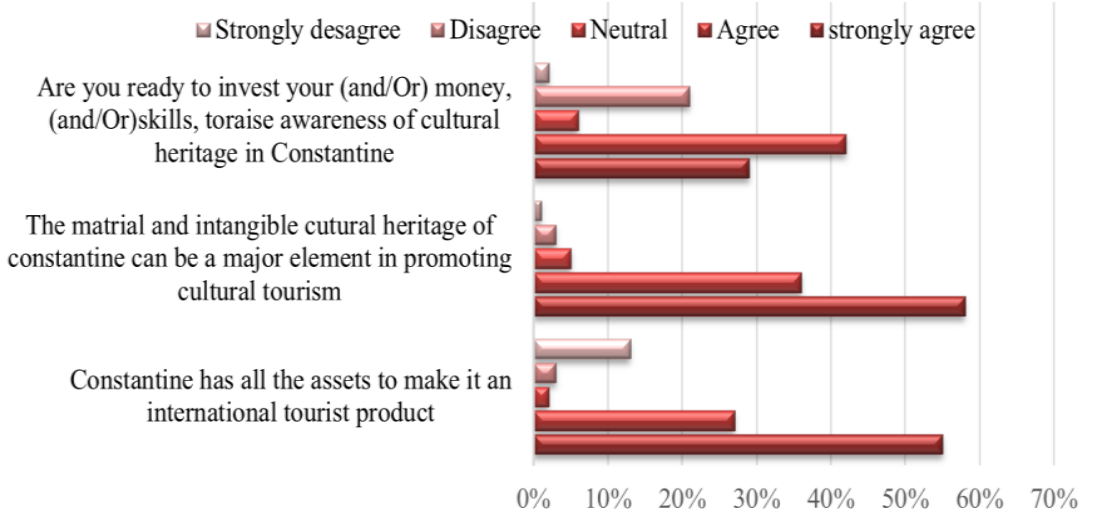

Figure 8. Perception of the local population regarding the development of cultural tourism in Constantine (Own results, 2020)

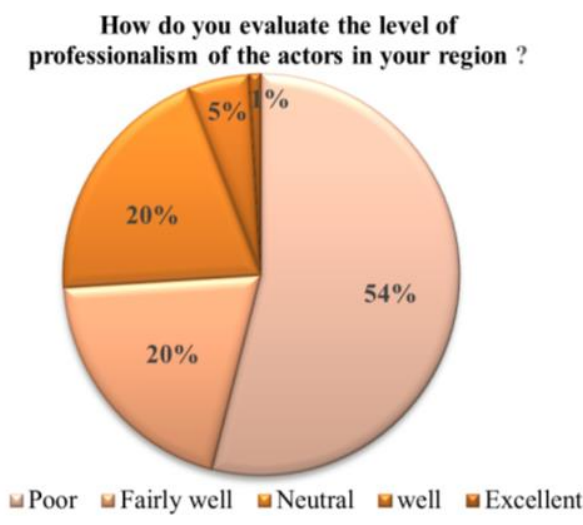

Figure 9. Professionalism level of tourism actors in Constantine (Own results, 2020)

Over half of the respondents (54\%) are not satisfied with the professionalism of the tourism actors in their city. They feel that these actors are poorly trained and therefore affect the promotion of tourism in the city (Figure 9). The first national network gathering all the actors of the tourism chain engaged in the development of tourism are the travel 
operators responsible of planning the tourist stays. They gather many services (airlines, hotels, restaurants, tourist guides). For this reason, their professionalism must be improved and the actors must commit to keep enhancing their tourism sector to create a dynamic tourism activity and a cooperation between the main operators working in the sector. The first axis of the survey contained questions that were designed to determine what cultural tourism means to the local population of Constantine, how they perceive the development of this type of tourism in their city and how they view the heritage and cultural potentialities that exist in the territory of Constantine. Although the individuals in our sample have a relatively high level of education, the results of the study indicate that cultural tourism remains a vague concept for the vast majority of Constantine's inhabitants. In addition, they lack sufficient understanding of the meaning of cultural tourism due to the limited tourist culture of Constantine's inhabitants in particular and of Algerians in general.

The questions of this study revolved around the cultural heritage of Constantine (tangible and intangible), the results of the study enabled to confirm that local inhabitants attach great importance to the local cultural heritage and are aware of the heritage assets value of their city, and encourage the exploitation of these in the tourist activity. This would highlight the counter hypothesis that the development of cultural tourism does not depend on the potentialities that cover the territory, but on the way it is perceived by the local actors. Nevertheless, in the 2nd axis and according to the obtained results we can reject the counter hypothesis and not refuse the "null hypothesis" in this case, the local actors do not play an active role in the preservation of the heritage in the city of Constantine, because they do not promote and develop the tourist products of this region and are not committed to the protection and conservation of cultural heritage. These comments allowed us to draw a series of conclusions presented in a table exhibiting the triggering factors and the strong points and actions to be considered for the development of a cultural tourism in the Constantine city (Table 6).

Table 6. Factors to be taken into account for the development of cultural tourism in Constantine

\begin{tabular}{|c|c|}
\hline ng factors & Action \\
\hline $\begin{array}{l}\text { Undeniable cultural tourist assets } \\
\text { (tangible, intangible) of } \\
\text { Constantine and the diversity of } \\
\text { its natural landscapes and climate }\end{array}$ & $\begin{array}{l}\text { Better exploitation of the tourism sector because it plays a primordial role in the economy of several } \\
\text { countries. (A sector that creates jobs and a factor of socio-economic balance). } \\
\text { The promotion and development of tourist products adapted to the exploitation of the diversity of the wealth. } \\
\text { The early presence of professional practice placements in tourism programs illustrates this (Airey, 2008) }\end{array}$ \\
\hline & $\begin{array}{l}\text { Can become a major attraction for the city and a destination of choice for all types of tourists. } \\
\text { The enhancement of the most characteristic sites and monuments of Constantine's history. }\end{array}$ \\
\hline $\begin{array}{l}\text { An intellectual elite interested } \\
\text { in the development of cultural } \\
\text { tourism }\end{array}$ & $\begin{array}{l}\text { Promote post-graduate training (Master/Doctorate) focused on tourism, which should include high } \\
\text { quality studies in the most prestigious universities. } \\
\text { To increase the demand for training in the field of tourism and catering in accordance with } \\
\text { international standards. } \\
\text { The modernization of tourism activities and the training of well qualified personnel } \\
\text { Obtain support from the Algerian state to provide funds to local and foreign individuals wishing to invest } \\
\text { in tourism infrastructure, offering short-term and mid-term tax benefits.(Souiher et Rezzaz, 2020) }\end{array}$ \\
\hline $\begin{array}{l}\text { An intellectual elite interested } \\
\text { in the development of cultural } \\
\text { tourism }\end{array}$ & $\begin{array}{l}\text { Involve the public authorities with their ideas and knowledge and engage the local population in the } \\
\text { promotion of tourism. } \\
\text { Encourage stakeholders to be engaged } \\
\text { Create a political and social culture of dialogue needed by the population of Constantine. } \\
\text { Allow the people concerned to express themselves } \\
\text { Connecting policy makers and citizens. } \\
\text { Implementation of programs through local community presentations } \\
\text { To support the cooperation between tourism agents and the community involved in the development } \\
\text { of cultural tourism. (Alves, 2018a). } \\
\text { Harder infrastructures such as educational and research institutes cultural facilities and high-grade } \\
\text { communication channels (Cooke et Lazzeretti, 2008) }\end{array}$ \\
\hline
\end{tabular}

In order to model the purpose of this study, a study purpose categorization model (SPIP) was conducted based on the following principles (Safing / Participating / Influence / Promoting) inspired by the Brazilian model of (Alves, 2018).

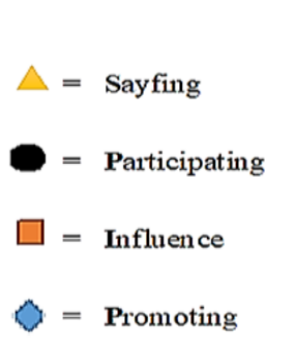

LD : Local development

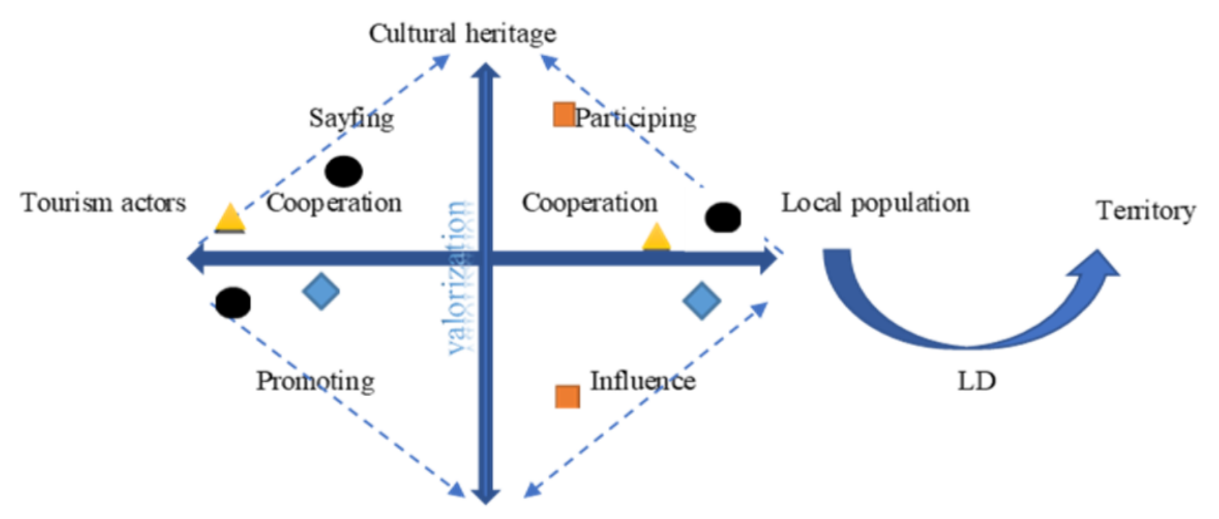

Cultural tourism 
The population participation in the process of tourism development, however, this approach integrates civil society through the awareness of civil society to the importance of cultural heritage. Moreover, it ensures the understanding of tourism with the development of educational and informative materials aimed at the general public with a simple language, illustrated with local real and accessible to attract the intention and interest of the inhabitants of Constantine (Hanai et al., 2011). The government has implemented many programs and plans to resolve those problems. All failed because they took a political approach based on centralised management which neglected the participation of local actors (Alouat, 2019). Understanding the relationship between information and technologies (ICT) and sustainable tourism industry is going to continue its growth and prosperity (Ali and Frew, 2014). It is also important to stimulate the use of ICT (Information and Communication Technology) in public administrations, so that information is safe and available everywhere and at any time, and to strengthen the use of ICT in tourism businesses by developing online services, as the internet has become today a fast way of use and a useful booking tool for tourists (Kelfaoui et al., 2021).How ICTs can be implemented to promote and measure well-being in tourism settings is, thus, a topic that that will continue to gain in importance (Gretzel and Stankov ,2021). Successful tourism development projects are those that involve society in decision-making, which is not the case in Constantine. There should be cooperation, between the private and the public sector (Petersen et al., 1999). Tourism education is an essential step that must be implemented in Constantine schoolchildren. This will allow children to better understand their territory and be more aware of tourism issues. This means implementing a tourist culture among the inhabitants from their young ages (Alves, 2018b).

The cohesion between all the concerned actors and the involvement of each part of the society is a very important step to concretize a model of cultural tourism development (SPIP) in Constantine, as shown in (Figure11).This model is based on the following two principles: "Sayfing, and Participating", the respect of these principles contribute to the awareness of cultural heritage protection (tangible and intangible). The illicit traffic of cultural goods and the revalorization of historical sites of the city and the improvement of the city's image. This can boost its attractiveness through the participation of the different actors of tourism, and the qualified and well-trained personnel to promote tourism. Thus the application of the principle "Promoting" because the cultural heritage specialists are considered more experienced and more competent than the other stakeholders of the destination, but without the help of the community they cannot become experts in heritage management. Even if cultural tourism has a positive impact on the territory, improves its economy and turns into a sector that creates jobs and contributes to local development. it is a factor of socio-economic balance, so the respect of all these elements contributes to the concretization of a model towards a development of local cultural tourism in the city of Constantine, exploiting their potentialities "cultural and natural" in the tourist activity while respecting the norms and the good practices for the exploitation.

\section{CONCLUSION}

The results of this study demonstrate a lack of awareness of cultural tourism among the region's inhabitants. It is therefore urgent to communicate these notions to the sector by showing the importance of cultural tourism and the extent of its positive impact on the local development of the region. The tourist culture is a notion that has become quite frequent in recent years in the vocabulary of tourism and constitutes an intrinsic product of development since it is presented as a Co-construction. This tourist culture finds its source in the traditions related to hospitality insofar as it is no longer limited to the behavior of tourists but rather as a fundamental element of the culture of the society (Kadri, 2021). All the elements of the study objectives categorization model are necessary and adequate conditions for the revitalization of tangible and intangible cultural heritage and therefore partnerships between the public and private sectors for the conservation of the historic urban environment play an increasingly essential role in the process of developing cultural tourism in the city. Interactive spaces are a way of new forms of power are created, as different social groups and individuals occupy distinct power positions in relation to different aspects of tourism development (Cole, 2006). Large built facilities located in tourist nodes have the best chance of being popular, so cultural venues must function primarily as attractions to be popular (McKercher et al., 2004).

Given the importance of this thousand-year-old city and its role as a regional capital and economic metropolis, and given its privileged geographical location, its administrative, economic, scientific and cultural weight, in addition to the other potentialities at its disposal, Constantine can welcome thousands of tourists every year, whether to work, trade, study or discover its undeniable heritage and cultural diversity, but without the association of its different elements of the model (Figure 10), tourism will not emerge in this city.

\section{REFERENCES}

Airey, D. (2008). La vie d'éducation touristique commence à 40 ans. Téoros. Revue de recherche en tourisme [Tourism education life begins at 40 Teoros]. Journal of Tourism Research Téoros, 27 (27-1), 27-32. http://journals.openedition.org/teoros/1617

Ali, A., \& Frew, A.J. (2014). ICT for sustainable tourism: a challenging relationship? Inf Technol Tourism 14, 261-264. https://doi.org/ $10.1007 / \mathrm{s} 40558-014-0020$

Alouat, M. (2019). Mobilising Women's Participation in Urban Development in the Southern Mediterranean. Case Study of Algiers Metropolitan Area. In Mediterranean Mobilities, 197-205, Springer, Cham. https://doi.org/10.1007/978-3-319-89632-8_16

Alloui-Ami Moussa, L.S. (2021). The putting territories into tourism, a tourism diagnosis tool case of the wilaya of Algiers. Geojournal of Tourism and Geosites, 35(2), 456-463. https://doi.org/10.30892/gtg.35225-672

Alves, D.S. (2018). Participation et tourisme: quelle place pour la population? Une étude exploratoire d'initiatives participatives au Brésil [Participation and tourism: what place for the population? an exploratory study of participatory initiatives in Brazil] . Doctoral Dissertation, University of Paul Vlery, MontpelierIII. https://tel.archives-ouvertes.fr/tel-01893860 
Astina, I.K., Sumarmi, \& Kurniawati, E. (2021). Tourism in Coastal Areas: Its Implication to Improve Economic and Culture Acculturation (Case Study in Goa China Beach, Malang). GeoJournal of Tourism and Geosites, 37(3), 740-746. https://doi.org/10.30892/gtg.37302-704

Baouali, R., Baziz, A., \& Hadjiedj, A. (2019). Comparative Competitiveness Indicators, Which Ranking For The Algerian Tourism? Geojournal of Tourism and Geosites, 24 (1), 133-145. https://doi.org/10.30892/gtg.24111-348

Belkhiri, A. (2018). Étude du rôle des acteurs locaux dans le développement du tourisme local. Cas de la ville de Bejaia Algérie. [Study of the role of local actors in the development of local tourism. Case of the city of Bejaia Algeria] Journal of Economics, Management and Commercial Sciences, 11(02), 507-519 https://www.asjp.cerist.dz/en/article/72452

Brohman, J. (1996). New directions in tourism for third world development. Annals of Tourism Research, 23(1), 48-70. https://doi.org/10.1016/0160-7383(95)00043-7

Cappucci, M. (2016). Indigenous tourism in the Amazon region of Suriname: actions to preserve authenticity and natural resources. GeoJournal of Tourism and Geosites, 17(1), 47-56. http://gtg.webhost.uoradea.ro/PDF/GTG-1-2016/193_Cappucci.pdf

Cárdenas-García, P.J., Sánchez-Rivero, M., \& Pulido-Fernández, J.I. (2015). Does tourism growth influence economic development? Journal of travel Research, 54(2), 206-221. https://doi.org/10.1177/0047287513514297

Cooke, P.N., \& Lazzeretti, L. (2008). Creative cities, cultural clusters and local economic development. Edward Elgar Publishing, Eds.

Cole, S. (2006). Cultural tourism, community participation and empowerment. In Cultural tourism in a changing world, 89-103, Publications Channel View. https://doi.org/10.21832/9781845410452-008

Cousin, S. (2008). L'Unesco et la doctrine du tourisme culturel [UNESCO and the Doctrine of Cultural Tourism]. Civilisations, 57(1), 41-56. https://doi.org/10.4000/civilisations. 1541

Čorak, S., \& Živoder, S.B. (2017). Tourism destination and DMO transformation. In Evolution of destination planning and strategy, 99118, Palgrave Macmillan, Cham. https://doi.org/10.1007/978-3-319-42246-6_6

Drouin, M. (2004). La sauvegarde d'un patrimoine urbain et la formulation d'une identité (Montréal, 1973-2003) [The preservation of an urban heritage and the formulation of an identity (Montreal, 1973-2003] Doctoral dissertation, Université of Québec, Canada.

Du Cros, H., \& McKercher, B. (2014). Cultural tourism. 1-10, Routledge. https://doi.org/10.4324/9780203790601

Ernawati, N.M., Sanders, D., \& Dowling, R. (2017). Host-guest orientations of community-based tourism products: A case study in Bali, Indonesia. International Journal of Tourism Research, 19(3), 367-382. https://doi.org/10.1002/jtr.2119

Girard, L.F., \& Nijkamp, P. (2009). Cultural tourism and sustainable local development. Ashgate Publishing, Ltd., Eds.

Goodwin, H. (2002). Local community involvement in tourism around national parks: opportunities and constraints. Current Issues in tourism, 5(3-4), 338-360. https://doi.org/10.1080/13683500208667928

Grelet, M., \& Vivant, E. (2014). La régénération d'un territoire en crise par la culture: une idéologie mise à l'épreuve. [The regeneration of a territory in crisis through culture: an ideology put to the test]. Belgeo. Revue belge de géographie, (1). http://belgeo.revues.org/12803

Grenier, E. (2007). Quelle est la «bonne» formule de l'écart-type? [What is the "right" formula for standard deviation?]. Revue Modulad, 102(37).

Gretzel, U., \& Stankov, U. (2021). TIC et bien-être: défis et opportunités pour le tourisme. [ ICT and well-being: challenges and opportunities for tourism]. Inf Technol Tourism 23, 1-4. https://doi.org/10.1007/s40558-021-00198-2

Hanai, F.Y., \& Espíndola, E.L.G. (2011). Programa de Sensibilização Sustentável do Turismo: uma proposta para envolvimento e participação de comunidades locais [Sustainable Tourism Sensitization: a program to engage and promote the participation of local communities] Revista Turismo em Análise, 22(1), 4-24. https://doi.org/10.11606/issn.1984-4867.v22i1p4-24

Janssen, J., Luiten, E., Renes, H., \& Stegmeijer, E. (2017). Le patrimoine comme secteur, facteur et vecteur : conceptualiser la relation changeante entre gestion du patrimoine et aménagement du territoire. [Heritage as sector, factor and vector: conceptualising the changing relationship between heritage management and spatial planning] Études d'urbanisme européen, 25 (9), $1654-1672$. https://doi.org/10.1080/09654313.2017.1329410

Kadri, B. (2021). Vocabulary of tourism discourse with the help of Marie De La Place, Alain A. Grenier and Yann.R.

Kelfaoui, A., Rezzaz, A.M., \& Kherrour, L. (2021). Revitalization of mountain rural tourism as a tool for sustainable local development in Kabylie (Algeria). The case of Yakouren municipality. GeoJournal of Tourism and Geosites, 34(1), 112-125. https://doi.org/ 10.30892/gtg.34115-62

Kherrour, L., Hattab, S., \& Rezzaz, M.A. (2020). Archaeological sites and tourism: protection and valorization, case of Timgad (Batna) Algeria, GeoJournal of Tourism and Geosites, 28(1), 25-36. https://doi.org/10.30892/gtg.28123-470

Kimbu, A.N., \& Ngoasong, M.Z. (2013). Centralised decentralisation of tourism development: A network perspective. Annals of Tourism Research, 40, 235-259. https://doi.org/10.1016/j.annals.2012.09.005

Krim, N. (2010). Tables de concertation et préservation du patrimoine, solution porteuse ou chimère? deux cas d'étude, le VieuxMontréal et le mont Royal [Discussion tables and heritage preservation, a promising solution or a chimera? two case studies, Old Montreal and Mount Royal].

Kodir, A. (2018). Tourism and Development: Land Acquisition, Achievement of Investment and Cultural Change (Case Study Tourism Industry Development in Batu City, Indonesia). GeoJournal of Tourism and Geosites, 21 (1), 253-265. https://doi.org/10.30892/gtg.21120-285

Lak, A., Gheitasi, M., \& Timothy, D.J. (2020). Urban regeneration through heritage tourism: cultural policies and strategic management. Journal of Tourism and Cultural Change, 18(4), 386-403. https://doi.org/10.1080/14766825.2019.1668002

Lekane Tsobgou, D., \& Schmitz, S. (2012). Le tourisme dit «ethnique»: multiples usages d'un concept flou [So-called "ethnic" tourism: multiple uses of a vague concept]. Bulletin de la Société Géographique de Liège, 59, 5-16. http://hdl.handle.net/2268/14323

MacDonald, R., \& Jolliffe, L. (2003). Rural Cultural Tourism: Evidence from Canada, 30(2), 307-322. https://doi.org/10.1016/S01607383(02)00061-0

Marlina, Sumarmi, Astina, I.K., \& Susilo, S. (2020). Social-Economic Adaptation Strategies of Bajo Mola Fishers in Wakatobi National Park. GeoJournal of Tourism and Geosites, 34(1), 14-19. https://doi.org/10.30892/gtg.34102-613

McKercher, B., Ho, P.S., \& Du Cros, H. (2004). Attributes of popular cultural attractions in Hong Kong. Annals of tourism rese arch, 31(2), 393-407. https://doi.org/10.1016/j.annals.2003.12.008

Morar, C., Grama, V., Stupariu, I.M., Nagy, G., Boros, L., Tiba, Gozner, M., \& Szabo-Alexi, S. (2020). Local perspectives over cultural tourism to heritage sites. the case study of oradea fortress (Romania). GeoJournal of Tourism and Geosites, 33, 1470-1479. https://doi.org/10.30892/gtg.334spl04-595

Naidja, H. (2017). L'attractivité territoriale des entrées de ville: Entre vecteur de développement local et support de marketing urbain. Cas de l'entrée sud de Constantine-Zouaghi/Ain El Bey [The territorial attractiveness of city entrances: Between a vector of local 
development and support for urban marketing. Case of the southern entrance to Constantine-Zouaghi / Ain El Bey]. Sciences \& Technologie. D, Sciences de la terre, 33-48. http://revue.umc.edu.dz/index.php/d/article/view/2230

Pecqueur, B. (2001). Qualité et développement territorial: l'hypothèse du panier de biens et de services territorialisés. Économie rurale, 261(1), 37-49. https://doi.org/10.3406/ecoru.2001.5217

Perrottet, T. (2002). On the trail of the ancient Roman tourists Route 66 A.D., 1st ed. New York, Random House, P.15

Petersen, P., \& Romano, J.O. (1999). Abordagens participativas para o desenvolvimento local. Assessoria e Serviços a Projetos em Agricultura Alternativa [Participatory approaches to local development. Advice and Services to Projects in Alternative Agriculture]. $144 \mathrm{p}$.

Prabhakaran, S., Nair, V., \& Ramachandran, S. (2014). Community participation in rural tourism: Towards a conceptual framework. Procedia-Social and Behavioral Sciences, 144, 290-295. https://doi.org/10.1016/j.sbspro.2014.07.298

Rahal, W., Rezzaz, M.A., \& Kherrour, L. (2020). The preservation of world archaeological sites and promotion of tourism: qala 'at bani hammad (M'sila) Algeria. GeoJournal of Tourism and Geosites, 33(4spl), 1571-1578. https://doi.org/10.30892/gtg.334spl19-6ze10

Reese, L.A., \& Fasenfest, D. (1997). Qu'est-ce qui marche le mieux ? Les valeurs et l'évaluation de la politique de développement économique local. [What works best? The values and evaluation of local economic development policy]. Développement économique trimestriel, 11 (3), 195-207.

Richards, G. (2013). Tourisme culturel. Dans le manuel Routledge d'études sur les loisirs[ Cultural tourism. In the Routledge Handbook of Leisure Studies ], Routledge, 505-514. https://www.academia.edu/3348330/Cultural_Tourism_and_Leisure_Studies

Šćitaroci, M.O., Šćitaroci, B.B.O., \& Mrđa, A. (2019). Cultural Urban Heritage: Development, Learning and Landscape Strategies. Eds. Springer. https://doi.org/10.1007/978-3-030-10612-6

Soualah, A., \& Benabbas-kaghouche, S. (2017). L'événementiel: moteur de valorisation du patrimoine et de mise en tourisme? Cas de Constantine Capitale de la culture arabe 2015[Events: a driving force for promoting heritage and promoting tourism? Case of Constantine Capital of Arab Culture 2015]. Sciences \& Technologie. D, Sciences de la terre, (45), 17-31. http://revue.umc.edu.dz/index.php/d/article/view/2229/2372

Souiher, K., \& Abdessamed Rezzaz, M. (2020). Rehabilitation of infrastructure in urban tourist areas (province of Algiers, Algeria). Loisir et Société/Society and Leisure, 43(3), 393-406.

Thomas, R. (2007). Tourism Partnerships and Small Firms: Power, Participation and Partition. The International Journal of Entrepreneurship and Innovation, 8(1), 37-43. https://doi.org/10.5367/000000007780007344

Suwantoro, G. (1997). Dasar-dasar Pariwisata [Tourism Basics], Yogyakarta. Andi Offset. https://doi.org/10.1080/07053436.2020.1849159

Thomas, B.E. (1955). Fortress City of Constantine, Algeria. The Scientific Monthly, 81(3), 130-137. http://www.jstor.org/stable/21967

Timothy, D.J. (2014). Contemporary cultural heritage and tourism: Development issues and emerging trends. Public Archaeology, 13(13), 30-47. https://doi.org/10.1179/1465518714Z.000000000052

Violier, P. (2008). Tourisme et développement local. [Tourism and local development] Belin. http://okina.univ-angers.fr/publications/ua16480.

Waridin, \& Astawa, I.P. (2021). Shifting Of Land Use In Sustainable Tourism: A Local Cultural Approach In Indonesia. Geojournal of Tourism and Geosites, 35(2), 270-274. https://doi.org/10.30892/gtg.35201-647

Yankholmes, A. (2018). Tourism as an Exercise in Three-Dimensional Power: Evidence from Ghana. Tourism Management Perspectives, 25, 1-12. https://doi.org/10.1016/j.tmp.2017.11.001

Zuo, B., Gursoy, D., \& Wall, G. (2017). Residents' support for red tourism in China: The moderating effect of the central government. Annals of Tourism Research, Elsevier, 64(C), 51-63. https://doi.org/10.1016/j.annals.2017.03.001

***FEM (2013.) Forum Économiques Mondial [World Economic Forum, 2013]

***ONS: Office Nationale des Statistiques [National Office of Statistics, (2011). The urban frame RGPH 2008]. The main results of the exhaustive exploitation. National Office of Statistics, Algiers, P. 213.

*** Organisation mondiale du tourisme (2014). Faits saillants OMT du tourisme, édition 2014 [World Tourism Organization (2014), UNWTO Tourism Highlights. Madrid]. https://doi.org/10.18111/9789284416219

***SDATW (2013). Schéma Directeur d'Aménagement Touristique de la wilaya de Constantine [The Master plan for Tourism Development in the wilaya of Constantine, Algeria] (Final edition).

Article history: Received: 03.08.2021 Revised: 17.11.2021 Accepted: 23.12.2021 Available online: 10.01 .2022 